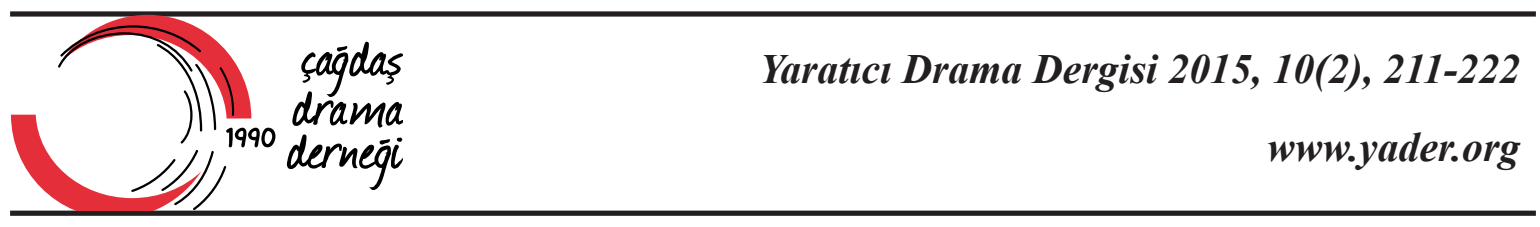

\title{
Is Creative Drama a Way to Excellence in ELT Classrooms?
}

\author{
Berna Güryay ${ }^{1}$
}

\begin{tabular}{|c|c|}
\hline Makale Bilgisi & Öz \\
\hline DOI: $10.21612 /$ yader.2015.018 & One of the most theoretical lessons in English Language Teaching (ELT) classrooms \\
\hline $\begin{array}{l}\text { Anahtar Sözcükler } \\
\text { Creative drama } \\
\text { English language teaching } \\
\text { Language acquisition lesson }\end{array}$ & $\begin{array}{l}\text { is 'Language Acquisition" which is in the programme of second grade students. In } \\
\text { order to make this lesson much more attractive and to introduce English language } \\
\text { teacher candidates to creative drama, a case study was carried out in Dokuz Eylül } \\
\text { University, ELT Department. The main objective of this study is to determine the } \\
\text { perceptions of prospective teachers on creative drama. The sample of this study } \\
\text { is composed of } 33 \text { second grade prospective teachers of Dokuz Eylül University, } \\
\text { ELT Department in the 2012-2013 spring term. This particular group were selected } \\
\text { randomly from the students who were taking language acquisition' lesson at the } \\
\text { time of the study. Within the scope of this study a-six hour-lesson plan, in which } \\
\text { creative drama was utilized, was prepared and the researcher herself taught in this } \\
\text { group. For data collection; an interview which was made with randomly selected } \\
\text { five students related to the creative drama process they experienced and a survey } \\
\text { which was administered as pre and post test were used. The results indicated that } \\
\text { prospective teachers of English agree on the effectiveness of creative drama in ELT } \\
\text { classrooms }\end{array}$ \\
\hline
\end{tabular}

\section{Yaratıcı Drama, İngiliz Dili ve Eğitimi Sınıflarında Mükemmelliğe Giden Yol mudur?}

\section{Article Info}

DOI: 10.21612 yader.2015.018

Keywords

Yaratıcı drama

Ingiliz dili ve eğitimi

Dil edinimi dersi

\begin{abstract}
Ingiliz Dili ve Eğitimi sınıflarındaki en teorik derslerden biri muhtemelen ikinci sınıf programında yer alan dil edinimi dersidir. Bu dersi daha çekici kılmak ve İngilizce ögretmenliği adaylarını yaratıcı drama ile tanıştırmak için Dokuz Eylül Üniversitesi, Ingiliz Dili ve Eğitimi Anabilim Dalı'nda bir olay incelemesi yapılmıştır. Bu çalışmanın ana amacı öğretmen adaylarının yaratıcı drama ile ilgili algılarını ortaya çıkarmaktır. Çalışmanın örneklemini 2012-2013 akademik yılında Dokuz Eylül Üniversitesi İngiliz Dili ve Ĕgitimi Anabilim Dalında okumakta olan 33 ikinci sınıf ögrencisi oluşturmuştur. Bu çalışma kapsamında yaratıcı dramanın yöntem olarak kullanıldiğ altı ders saatlik bir plan hazırlanmış ve bu planı araştırmacı uygulamıştır. Veri toplama aracı olarak, ilk ve son test şeklinde verilen bir anket ve rastgele seçilen beş ögrenci ile deneyimledikleri yaratıcı drama süreci hakkında yapılan görüşmenin kaydı kullanılmıştır.
\end{abstract}




\section{Introduction}

Dorothy Heathcote (Johnson, O’Neill, eds., 1991) argues that "in this work, drama, what we are trying to do is to make ordinary experiences significant, and that's a hard thing. That is the excellence we strive for"(p.24). The excellence Heathcote strives for is the subject of this paper. The fact that creative drama is closely related to real world makes it an invaluable tool for English Language Teaching classrooms. Therefore, English language teacher candidates may benefit from creative drama both in learning their subject areas and in their future professions (Güryay, 2012).

Creative drama is defined as "an improvisational, non-exhibitional, process-centered form of drama in which participants are guided by a leader to imagine, enact; and reflect upon human

experiences" (McCaslin, 1990,p.5). Adıgüzel (2010) also defines creative drama as a group's enactment of an aim, an idea with techniques such as improvisation, role-playing etc. by using the experiences of group members.

Creative drama can be utilized effectively in English language teaching classrooms because of several reasons. Burke and O'Sullivan (cited in Wood Shant, J.,2008) identified seven of these reasons to incorporate drama in the second language classroom:

1. Teachers and students can concentrate on pronunciation.

2. Students are motivated.

3. Students are relaxed.

4. Students use language for real purposes.

5. Risk-taking equals heightened language retention

6. Community is created.

7. Students and teachers can approach sensitive topics (p. 25).

Creative drama offers a unique opportunity to enlarge the vocabulary, promote more audible speech and improve articulation (McCaslin, 1990, p. 254). Creative drama has several positive effects in second language classrooms. Wagner (1998, p.53-55) proves drama to be effective in improving competence in a second language with five studies (Kao; Maranon; Planchat; Shacker, Juliebo\& Parker; Vitz, cited in Wagner,1998). All of these studies show that drama challenges students to use language for a much broader range of purposes than customary school dialogues. Another study which was carried out by Güryay (2014) indicates that creative drama can be an effective teaching method in English Language teaching classrooms and it helps to increase students' motivation and creativity. Naoko Araki-Metcalfe (2012) states the importance of creative drama in English language in the following lines:

Some students who were not actively engaged in their daily school lives, were "coming out of their shell", and were even leading others in some instances, by taking charge of some of the discussions. The students became totally immersed in their roles, and even surprised themselves sometimes as to how much they could communicate in the English language in a meaningful and purposeful way (p.73).

Creative drama offers a unique opportunity to enlarge the vocabulary, promote more audible speech and improve articulation (McCaslin, 1990, p. 254). Dervishaj, A.(2009) believes "Since 
learners use English for specific purposes, language is more easily internalized and, therefore, language is remembered. Drama provides the ultimate multi-sensory learning experience, it is inclusive and it supports the learning of a foreign language (p.58).

Gavin Bolton (2010) asserts that "there are four main aims that all drama teachers at all times have tended to maintain. There have been those who place an emphasis on content, promote drama for personal growth, see drama as a means of social development, and hold teaching about the dramatic art form as a priority" (p.45). Because prospective teachers will perhaps take these aims in the future, this study will analyze their perceptions on creative drama.

\section{Methodology}

Pre-test \& post-test experimental model has been employed in this study. The participants were 33 teacher candidates studying $2^{\text {nd }}$ grades in ELT Department, Dokuz Eylül University, during the academic year of 2012-2013. They were given a survey before and after the educational treatment. For the purpose of the study, a-six-hour lesson plan related to the factors affecting second language learning was prepared. The researcher herself taught in these lessons using creative drama. After the educational treatment an interview was conducted with the subjects. Details related to the subjects and data-collection will be given in this part of the study.

\section{Subjects}

The participants of the study are randomly chosen among second grade prospective teachers of Dokuz Eylül University, ELT Department in the 2012-2013 spring term. The subjects are 33 students who were taking 'language acquisition' lesson at the time of the study. In the year the study was carried out, they had 3 hours of 'language acquisition' lessons in a week. At the time of this educational treatment they were in the midst of the second semester.

\section{Data Collection Tools}

Within the scope of this study a survey and interview questions related to the participants' perceptions on creative drama was prepared by the researcher. Accordingly, before and after the educational treatment survey was administered to the sample group. Besides, randomly selected five students were interviewed after the educational treatment was over and these interviews were video recorded and analyzed.

\section{Findings}

The findings of the study related to the research questions are discussed in this part. The findings related to two main data collection tools; survey and interview are analyzed one by one in detail.

\section{Data Analysis of Survey Questions related to Creative Drama}

One of the most informative parts of this study is survey, which is about creative drama perception. The results of this survey which was administered to the subjects before and after the educational treatment are given in this part. 


\section{English Language Teacher Candidates' Definition of Creative Drama}

In Table 1 English Language Teacher Candidates' definitions of creative drama before the educational treatment in which creative drama was used is given. According to this table 16 students out of 33 did not answer this question which indicates they have not enough knowledge related to "creative drama". 7 students said that they do not know what creative drama is. 5 students defined creative drama generally as "improvisation".

Table 1. English Language Teacher Candidates' Definition of Creative Drama in Pre-test

\begin{tabular}{|l|c|c|}
\hline Perceptions/Code & Student code numbers & F (frequency) \\
\hline No answer & $4,7,9,10,11,15,18,19,22,23,24,26,27$, & 16 \\
I do not know & 28,32 & 7 \\
Improvisation & $6,13,29,14,25,30,33$ & 5 \\
Sketch & $2,12,1,17,20$ & 1 \\
Creativity & 1 & 1 \\
Helps feeling oneself much more relaxed & 2 & 1 \\
in society & 16 & 1 \\
Confidence & 20 & 1 \\
$\begin{array}{l}\text { Drama which emphasizes the imagination } \\
\text { of students }\end{array}$ & 9 & 2 \\
$\begin{array}{l}\text { Making lessons easier and more } \\
\text { comprehensible }\end{array}$ & 1,21 & \\
\hline
\end{tabular}

Table 2 illustrates the perception of prospective English teachers related to creative drama after they have been educated with creative drama for two weeks. Six of the participants defined creative drama as 'improvisation', while five defined it as 'Something which makes learning easier by means of making lesson enjoyable'. Another five of the students underlined the importance of "working in groups" in creative drama; whereas, five students did not answer this question.

Table 2. English Language Teacher Candidates' Definition of Creative Drama in Post-test

\begin{tabular}{|l|c|c|}
\hline Perceptions/Code & Student code numbers & F (frequency) \\
\hline No answer & $4,13,14,15,22$ & 5 \\
I do not know & - & - \\
Sketch & 1 & 1 \\
Improvisation (in the lesson) & $8,16,17,23,26,28$ & 2 \\
\hline Using creativity & 9,23 & 2 \\
\hline Animation/Enactment in the classroom & 21,29 & 1 \\
\hline Students' production of something by their efforts & 23 & 1 \\
\hline $\begin{array}{l}\text { An activity which helps students to learn by means } \\
\text { of playing }\end{array}$ & 3 & \\
\hline
\end{tabular}




\begin{tabular}{|l|c|c|}
\hline $\begin{array}{l}\text { Something which makes learning easier by means of } \\
\text { making lesson enjoyable }\end{array}$ & $5,6,30,31,28$ & 5 \\
\hline $\begin{array}{l}\text { Short plays which give the gist of the lesson with } \\
\text { one word or sentence }\end{array}$ & 10,32 & 2 \\
\hline Dramatization of the subject of a lesson & 11,21 & 2 \\
\hline $\begin{array}{l}\text { Making the lesson easier to understand by means of } \\
\text { some activities }\end{array}$ & 9,12 & 2 \\
\hline $\begin{array}{l}\text { It is a kind of drama in which students improvise a } \\
\text { subject in groups. }\end{array}$ & 19 & 1 \\
\hline $\begin{array}{l}\text { To form groups of students and ask them to practise } \\
\text { in order to make them understand the subject or } \\
\text { learn a new subject }\end{array}$ & 18 & 2 \\
\hline $\begin{array}{l}\text { A method which helps learning much more } \\
\text { effectively. We rescue students from being passive } \\
\text { by making them active }\end{array}$ & 20,24 & 1 \\
\hline $\begin{array}{l}\text { A kind of teaching method which puts the student at } \\
\text { the focal point }\end{array}$ & 33 & 1 \\
\hline $\begin{array}{l}\text { An activity which helps the student to learn } \\
\text { naturally, without feeling stressed }\end{array}$ & 27 & 1 \\
\hline Ensuring the children to find and form themselves & 32 & \\
\hline Working in groups & & \\
\hline $\begin{array}{l}\text { Learning by practice and adaptation as if it really } \\
\text { happens }\end{array}$ & & \\
\hline
\end{tabular}

English Language Teacher Candidates' thoughts related to whether creative drama can be used in ELT classrooms

In this part of the survey participants were asked 'Do you think that creative drama can be used in ELT classrooms?'. In table 3 their answers before the educational treatment with creative drama started are shown. According to this table, 16 participants stated that creative drama can be used in ELT Classrooms. One of the students is not sure about this subject and 16 students did not answer this question.

Table 3. English Language Teacher Candidates' thoughts related to whether creative drama can be used in ELT classrooms in pre-test

\begin{tabular}{|l|c|c|}
\hline Perceptions/Code & Student code numbers & F (frequency) \\
\hline Yes & $1,2,3,7,9,11,12,13,17,18,20,23,27,30,32,33$ & 16 \\
No answer & $4,5,10,14,15,16,19,21,22,24,25,26,28,29,8$ & 16 \\
Maybe &, 31 & 1 \\
& 6 & \\
\hline
\end{tabular}


Table 4 shows participants' ideas related to whether creative drama can be used after the educational treatment is over, are given. The number of the participants who think that it can be used in ELT classrooms increased from 16 to 29 after the lessons with creative drama. Four participants did not answer this question.

Table 4. English Language Teacher Candidates' thoughts related to whether creative drama can be used in ELT classrooms in post-test

\begin{tabular}{|l|c|c|}
\hline Perception Code & Student code numbers & F frequency \\
\hline Yes & $1,2,3,5,7,6,8,9,10,11,12,13,15,16,17,18,19,20,21,23,24,2$ & 29 \\
No & $5,26,27,29,28,30,31,33$ & - \\
No answer & - & 4 \\
\end{tabular}

\section{English Language Teacher Candidates' thoughts related to how creative drama can be used in ELT classrooms}

Related to the question 'can creative drama be used in ELT classrooms?', the participants were asked "If yes, how can creative drama be used in ELT classrooms?". The answers to this question are given in the two tables below.

Table 5 indicates that before the educational treatment, 18 participants did not answer this question and two of them said they did not know how creative drama can be used,. Two participants stated that it can be used by means of enjoyable activities. Other ideas related to the usage of creative drama in ELT are; by games (1), by interaction (1), by creativity (1), by making students extrovert (1) and feel good (1), with the help of improvisation (1) and dialogues (1). The assumption that 'learning English by living it, will increase retention' (1) is another perception.

Table 5. English Language Teacher Candidates' thoughts related to how creative drama can be used in ELT classrooms in pre-test

\begin{tabular}{|l|c|c|}
\hline Perceptions/Code & Student code numbers & F (frequency) \\
\hline I don't know & 2,33 & 2 \\
No answer & $4,5,10,13,14,15,19,21,22,24,25,26,28,32$, & 18 \\
We can make them play games related to & $6,8,30,31$ & 1 \\
the subject & 3 & 1 \\
We can make them do creative drama as & 12 & 1 \\
they like at that moment & & 1 \\
\hline By means of interaction & 12 & 1 \\
By means of creativity & 12 & 1 \\
By making students extrovert & 16 & 1 \\
By making students feel good & 16 & \\
By providing appropriate atmosphere for & 17 & 1 \\
the students to learn & & \\
\hline
\end{tabular}




\begin{tabular}{|l|l|l|}
\hline With the help of improvisation & 18 & 1 \\
With the help of dialogues & 18 & 1 \\
By means of (enjoyable) activities & 11,23 & 2 \\
By means of informative activities & 23 & 1 \\
Learning English by living it will & 27 & 1 \\
increase retention & 9 & 1 \\
Different roles are given to the student & &
\end{tabular}

In table 6 after the educational treatment, the participants' thoughts related to how creative drama can be used in ELT classrooms are given. Four participants did not answer this question. A great number of students (12) indicated that it can be used by improvisation (4), by animation (4) and by group work (4). Other common ideas are using it in vocabulary teaching (3) and addressing different senses (2).

Table 6. English Language Teacher Candidates' thoughts related to how creative drama can be used in ELT classrooms in post-test

\begin{tabular}{|c|c|c|}
\hline Perceptions/Code & Student code numbers & F (frequency) \\
\hline I don’t know & - & - \\
\hline No answer & $4,14,22,32$ & 4 \\
\hline $\begin{array}{l}\text { We can transform the subjects of the lesson into } \\
\text { enjoyable games }\end{array}$ & 3 & 1 \\
\hline By means of interaction & 26 & 1 \\
\hline By making students feel good (affectively) & 33 & 1 \\
\hline $\begin{array}{l}\text { By providing appropriate atmosphere for the students to } \\
\text { learn }\end{array}$ & 31 & 1 \\
\hline With the help of improvisation & $2,16,18,28$ & 4 \\
\hline With the help of dialogues & 18 & 1 \\
\hline By means of (enjoyable) activities & 21 & 1 \\
\hline By means of informative activities & 9 & 1 \\
\hline Learning English by living it will increase retention & 8,15 & 2 \\
\hline $\begin{array}{l}\text { Different roles (related to daily life) are given to the } \\
\text { student }\end{array}$ & 6 & 1 \\
\hline $\begin{array}{l}\text { Animation/Enactment can be done in the scope of } \\
\text { drama( which can be enjoyable) }\end{array}$ & $1,17,29,33$ & 4 \\
\hline By means of group work & $2,19,26,29$ & 4 \\
\hline By transforming lesson subjects into enjoyable games & 3 & 1 \\
\hline $\begin{array}{l}\text { By addressing different senses such as visual, auditory, } \\
\text { kinaesthetic }\end{array}$ & 5,15 & 2 \\
\hline
\end{tabular}




\begin{tabular}{|l|c|c|}
\hline $\begin{array}{l}\text { Teaching the subject by making the students create plays, } \\
\text { stories and songs and by playing them. }\end{array}$ & 11 & 1 \\
\hline By adapting creative drama into English & 20 & 1 \\
\hline In vocabulary teaching & $7,13,23$ & 1 \\
\hline In grammar teaching & 23 & 1 \\
\hline In role-play activity, in an enjoyable way & 24 & 1 \\
\hline By means of examples learning will be easier & 25 & 1 \\
\hline It develops students' speaking ability & 26 & 1 \\
\hline $\begin{array}{l}\text { By helping students learn English unconsciously and by } \\
\text { making them like English }\end{array}$ & 27 & \\
\hline By determining and teaching objectives & 30 & \\
\hline
\end{tabular}

\section{Data Analysis of Interviews on Creative Drama}

Within the scope of the study, five students out of 33 students were randomly selected on a volunteer basis. Detailed description of the main parts of the students' perception related to creative drama and how it can be used in ELT classrooms are given in the following part. The pseudonym of the participant is included with his/her quotation.

\section{Creative drama can be used in ELT}

All of the students interviewed, agreed on the convenience of creative drama for ELT classrooms. Tülin claimed that it can not only be used in second language classrooms but also in all other lessons. Another student, Ece, stated that "I think creative drama can be used and it will develop students' speaking ability". Özlem and Burcu share the view that it can be used in ELT classrooms. Özlem adds that it is a good method and should certainly be used in ELT classrooms and it will increase creativity. Burcu states that creative drama is much more utilizable and effective than classical teaching methods. She explains that she has not taken drama lessons but with the educational treatment, in which creative drama has been used, she has seen how effective it is and she asserts that she will use creative drama in her future career. Yiğit also thinks it can be used if the conditions are convenient, for instance if the population of the class is not too much.

\section{Creative drama, which is done with a group, is effective for interaction}

Three participants indicated that creative drama is helpful in interaction which is an indispensable part of a second language classroom. One student teacher described creative drama as in the following quotation; "Creative drama is done with a group and people are in interaction" (quotation from Özlem's interview). Tülin also tells that they worked in groups of two or three members in creative drama and Ece claims that creative drama ensures social interaction.

\section{Creative drama is effective in speaking}

One of the students underlines the importance of speaking in learning a second language and argues that creative drama is very effective in developing speaking: "English language teaching requires speaking a lot. Creative drama assures both speaking and social interaction. Speaking is 
already at the centre of our second language. I think creative drama can develop speaking" (quotation from Ece's interview).

\section{Creative drama is effective in vocabulary}

Creative drama has been found effective for teaching vocabulary by one of the students. She stated that: "When we first started lesson with creative drama we didn't know the meanings of those words. When we started acting them in groups we acquired the unknown words. If you ask the words now, I remember my friends' act outs and I can keep them in my mind more". In vocabulary teaching if you give the words like that, they will retain more in the memory. All in all, the things we see retain more than the things we just hear". (Tülin)

\section{Creative drama is effective in retention}

One of the participants underlines that the things which are learnt with creative drama is remembered more; "In vocabulary teaching if you give the words like that (with creative drama), they will retain more in the memory. All in all, the things we see retain more than the things we just hear". (Tülin). Another participant declared that "the sketch like improvisations we did has been long-lasting” (Burcu).

\section{Creative drama helps self-regulation}

One of the students pointed out that creative drama can help self-regulation of the students. She explains; "Student can develop her/his self-regulation. This is very important in second language learning. I think it will be very beneficial” (Ece).

\section{Creative drama is enjoyable}

Two of the interviewees share the view that creative drama is enjoyable. "Creative drama is an enjoyable learning method. The ones who watch the improvisations also enjoy the lesson. If we begin to use creative drama from childhood, it would be better.(Özlem's quotation). Another student who shares this view says that creative drama opposes the boredom of other teaching methods; "Other methods decrease students'attention and motivation towards the lesson...Creative drama can be used more than other normal methods and it is much more effective" (Burcu). Even the student who finds creative drama strange accepts that it is enjoyable and they would be happy if all the lessons were done with creative drama: “...but it is enjoyable, we can't deny it. We agree if all of our lessons were like that. Insomuch..."(Yiğit)

\section{Creative drama is strange}

One of the participants of the study admits that he has found creative drama a little bit strange. He has some worries about the application of creative drama in highly populated classrooms: "If we use creative drama in primary school, I'm afraid there will be too much noise and cooperation will be a problem...I may be a trouble for the teacher, otherwise, for the students life is good. High school, especially language classes-for instance we were 11 students-is ideal for creative drama. However, primary school or university in which a class is composed of 40 or 50 students it can be difficult" (Yiğit). As the quotation suggests, this student is worried about the practice of creative drama because of physical conditions of different classrooms and he adds that if the conditions are convenient, creative drama is an enjoyable method to teach in ELT classrooms. 


\section{Discussion}

Before the educational treatment with creative drama, more than half of the prospective teachers of English did not have any idea about what creative drama is. However, after a six-hour lesson with creative drama they started to define it as improvisation (6), something which makes learning easier by means of making lesson enjoyable (5), working in groups (5) and using creativity (2), enactment (2) and dramatization (2). Their perception is generally in parallel with the features of creative drama. They underline the importance of improvisation, group work, its being learner centered, effective and enjoyable learning. Nevertheless, some of them confuse it with dramatization and sketch. The reason of this confusion may be their background knowledge where they used role-plays and dramatizations. Another question of the survey is whether creative drama can be used in ELT classrooms. Before the educational treatment, 16 participants answered "yes" and after the educational treatment, this number increased to 29 participants. The radical change indicates that after their creative drama experience, they liked creative drama and this affected their ideas positively. As prospective teachers of English they think that creative drama can be implemented in ELT classes. The participants were also asked how creative drama can be used in ELT classrooms. In pre-test most of the students did not answer this question and the ones who answered stated that it can be used by means of enjoyable activities, and by means of creativity, interaction, by making students extrovert and by making students feel good. After the educational treatment, a great number of students answered as with the help of improvisation, enactment and group work. Creative drama was also found important in vocabulary teaching and addressing to different senses. This implies that after the educational treatment, prospective teachers of English have found out how they can use creative drama in their classes. These results are in parallel with the study by Güryay (2014) whose results indicate English language teacher candidates are willing to learn creative drama and use it in their future professions.

The second data collection tool, interview supplied similar results about the participants' perception of creative drama. The interviewees shared the view that creative drama can be used in ELT classrooms. However, one of the students has some doubts because of the high population of some classrooms. This disadvantage can be considered in the planning of lessons with creative drama. The participants indicated that creative drama is effective in speaking, vocabulary, retention and it helps self-regulation. What is more, it is characterized as being enjoyable. These positive features are stated by all of the interviewees, even by the student who has found creative drama strange. The reason of his finding creative drama strange may be related to its being new for them. Creative drama in Turkey, in contemporary sense, started with İnci San and Tamer Levent's meeting in 1980s (Adigüzel, 2010,p.261). This date may be considered as new with regards to a nation's education understanding and style.

\section{Conclusion}

Creative drama which is "the individual's explanation and enactment of an experience, an event, an idea, an abstract concept and behaviour in play-like processes where observation, experience and feelings are considered with the help of theatre and drama techniques by a group" (San, 2006) is introduced to future English language teachers. Before this introduction they had little idea about creative drama. After their lessons with creative drama they gained insight related to creative drama. 
Although they did not take any theoretical lessons about creative drama they used the terms in San's (2006) definition above. They used enactment, improvisation, group work, experiences in their definition related to creative drama. They also underlined its effectiveness in language learning, especially vocabulary, speaking and retention. As Winston (2004) declares "Drama more than any other subject in the curriculum, mirrors life as it is lived and experienced...Language can therefore be experienced-heard, interpreted and used in contexts that seem real to children"(p. 18).

All in all, the fact that prospective teachers of English like creative drama and know how they can use it effectively in their future classrooms is very important. This study aimed to learn their perceptions and attitudes towards creative drama after a brief introduction with creative drama. the results indicated that they perceived creative drama as an effective and enjoyable way to teach a second language.

\section{Suggestions}

The results of this study have been encouraging in the field of creative drama in ELT. However, a number of suggestions can be given for further studies:

- The participants of this study are prospective teachers of English. The participants can be selected among second language learners from different levels.

- The number of the participants can be increased and the study can be conducted again.

- The amount of time for the educational treatment can be increased.

- The participants can be given enough theoretical lessons related to creative drama because some of them have still some problems related to the definition and usage of creative drama.

- According to a student creative drama is difficult to use in high populated classrooms. This claim can be investigated with further research. If it is found as a disadvantage some solutions can be searched for.

- This study only analyzed the participants' perceptions related to creative drama. The effects of creative drama on other factors such as achievement can also be analyzed.

\section{References}

Adıgüzel, Ö. (2010). Ĕgitimde yaratıcı drama. Ankara: Naturel Yayınevi.

Bolton, G. (2010). New perspectives on classroom drama. In Davis (ed.), D. Gavin Bolton Essential Writings (pp.45-62). Great Britain: Trentham Books.

Dervishaj, A.(2009) Using Drama as a Creative Method for Foreign Language Acquisition. LCPJ, vol:2/1, 53-62.

Güryay (2012). The use of creative drama. In Çubukçu, F (ed.). Teaching Skills "From Theory to Practice" (p.209-225). Ankara: Nobel Yayıncilık.

Güryay (2014) Creative drama: A way to understand Shakespeare? Procedia- Social and Behavioural Sciences. 116 ( 2014 ) $1127-1131$.

Johnson, 1., O’Neill, C. (1991). (Ed.). Collected writings on education and drama, Dorothy Heathcote. Evanston, Illinois: Northwestern University Press. 
McCaslin (1990). Creative drama in the classroom. California: Players' Press Inc.

Naoko Araki, M. (2012). We are robot engineers! Drama pedagogy as the core of an integrated curriculum unit for learning English as a foreign language. Creative Approaches to Research. vol. 5. 3, 62-74

San, İ. (2006). Yaratıcı dramanın eğitsel boyutları. In Adıgüzel, H. Ö. (Ed.), Yaratıcı Drama 1985-1998 Yazılar (pp. 113-122). Ankara: Naturel Yayınları.

Shand Wood, J. (2008). The use of drama to reduce anxiety and increase confidence and motivation towards speaking English with two groups of English language learners. Unpublished Master of Arts Thesis, The University of Arizona, USA.

Wagner, B.J. (1998). Educational drama and language arts, what research shows. Portsmouth, USA: Heinemann.

Winston (2004). Drama and English at the heart of the curriculum. London: UK: David Fulton publishers. 